\title{
NASKAH MELAYU DIGITAL: SEBUAH INOVASI SUMBER KAJIAN PENDIDIKAN ISLAM BERBASIS INFORMATION AND COMMUNICATION TECHNOLOGY (ICT)
}

\section{DIGITAL MELAYU MANUSCRIPT: AN INNOVATION IN SOURCE OF ISLAMIC EDUCATION STUDY BASED IN INFORMATION AND COMMUNICATION TECHNOLOGY (ICT)}

\author{
Ellya Roza \\ Universitas Islam Negeri Sultan Syarif Kasim Riau, Indonesia \\ Email: ellyaroza@uin-suska.ac.id \\ Mudasir \\ Universitas Islam Negeri Sultan Syarif Kasim Riau, Indonesia \\ Email: mudasir@uin-suska.ac.id
}

\begin{abstract}
Abstrak
Tulisan ini bertujuan untuk mengetahui naskah Melayu digital sebagai sumber kajian bidang pendidikan Islam. Naskah Melayu adalah salah satu dokumen bangsa yang ditulis secara manual dengan menggunakan aksara Arab-Melayu dan berbahasa Melayu. Artinya naskah Melayu adalah goresan kalam local genius bangsa dan merupakan icon intelektualitas masyarakat pada zamannya. Namun seiring dengan kemajuan teknologi, maka naskah Melayu pun mengalami perkembangan melalui teknologi tersebut dengan cara digitalisasi. Dari segi metodologi, tulisan ini merupakan kajian terhadap peninggalan sejarah dan budaya dengan melibatkan naskah Melayu, maka kajian ini menggunakan metode deskriptif kualitatif yang dikaitkan dengan analisis dan interpretasi dan akhirnya menfokuskan kepada content analysis. Di akhir kajian ditemukan bahwa selain al-Qur`an dan Hadis yang menjadi sumber kajian pendidikan Islam, ternyata naskah Melayu digital dapat dijadikan sumber berikutnya, karena naskah Melayu merupakan tinggalan warisan budaya yang sarat dengan nilai-nilai luhur kehidupan seperti sosial, politik, agama, pendidikan, kebudayaan, ekonomi, bahasa, sastra dan lain sebagainya. Oleh karena itu, naskah Melayu digital merupakan sebuah inovasi berbasis ICT yang dapat dijadikan sumber kajian pendidikan Islam. Naskah Melayu digital sangat mudah diperoleh karena di berbagai tempat penyimpanan naskah Melayu telah melakukan digitalisasi sehingga para ilmuwan dapat memanfaatkannya. Selain itu, Naskah Melayu digital dapat diakses melalui internet dengan berbagai situs.
\end{abstract}

Kata Kunci: berbasis IT, naskah Melayu digital, pendidikan Islam. 


\begin{abstract}
This paper aims to find out the digital Malay manuscript as a source of studies in the field of Islamic education. Malay manuscript is one of the nation's documents written manually using Arabic-Malay characters and in Malay. This means that the Malay manuscript is a stroke of the local genius of the nation and is an intellectual icon of the people of his day. But along with advances in technology, the Malay manuscript also experienced development through this technology by means of digitalization. In terms of methodology, this paper is a study of historical and cultural heritage involving Malay manuscript, so this study uses descriptive qualitative methods that are linked to analysis and interpretation and finally focuses on content analysis. At the end of the study it was found that in addition to the Quran and Hadith which are the sources of Islamic education studies, it turns out that the digital Malay manuscript can be used as the next source, because the Malay manuscript is a legacy of cultural heritage that is loaded with noble values of life such as social, political, religious, educational, culture, economics, language, literature and so on. Therefore, digital Malay manuscript is an ICT-based innovation that can be used as a source of study of Islamic education. Digital Malay manuscripts are very easy to obtain because in various places where Malay manuscripts have been digitalized, scientists can use them. In addition, digital Malay manuscripts can be accessed through the internet with various sites.
\end{abstract}

Keywords: ICT-based, Islamic education, digital Malay manuscripts

\title{
A. Pendahuluan
}

Produk masyarakat masa lalu yang dapat dimanfaatkan oleh masyarakat sekarang salah satunya adalah hasil goresan kalam mereka yang dikenal dengan istilah naskah. Namun naskah tersebut lama-kelamaan juga akan mengalami kehancuran akibat kondisi alam dan usia yang tua karena telah ditulis beratus-ratus tahun yang lalu sementara penyimpanannya tidak memadai. Selain itu juga dikarenakan oleh alas tulis yang amat sangat sederhana seperti kertas daluwang, kertas impor, pelepah daun, kulit kayu, kulit binatang dan lain sebagainya, maka naskah tersebut akan mengalami pelapukkan yang menyebabkan fisik naskah hancur dan jika sudah hancur tentu saja kandungan teksnya tidak dapat dibaca.

Penamaan naskah Melayu dikarenakan naskahnya ditulis dengan menggunakan aksara Arab-Melayu dan berbahasa Melayu. Meskipun sebenarnya aksara Arab telah digunakan sebagai bahasa tulisan sejak masyarakat mengenal tulis baca yang belum 
terjadi pada masa awal kedatangan agama Islam. ${ }^{1}$ Oleh karena itu, naskah Melayu merupakan warisan budaya masa lampau yang patut dirawat serta diselidiki kandungan isnya karena naskah sarat dengan nilai-nilai luhur yang mencakup segala aspek kehidupan seperti sosial, politik, agama, kebudayaan, ekonomi, bahasa, sastra dan lain sebagainya yang bersifat historis dan didaktis. Dengan demikian, naskah dipandang mampu menjelaskan informasi yang terjadi pada zamannya. Dari tulisan-tulisan tersebut dapat diperoleh gambaran lebih jelas mengenai alam pikiran, adat istiadat, kepercayaan dan sistem nilai pada orang pada masa lampau, suatu pengertian yang tidak mungkin tercapai jika bahan-bahan keterangan hanya terdiri dari peninggalan material. ${ }^{2}$

Pendidikan Islam adalah pendidikan yang mengajarkan ajaran-ajaran Islam melalui bimbingan dan asuhan terhadap anak didik agar nantinya dapat memahami dan menghayati serta mengamalkan ajaran Islam sebagai suatu pandangan hidup di dunia dan di akhirat. ${ }^{3}$ Artinya, pendidikan secara umum dan pendidikan Islam khususnya sangat diperlukan oleh setiap individu, karena tanpa pendidikan tidak mungkin akan melahirkan generasi yang terampil dan tangkas yang sanggup menghadapi tantangan masa depan. Oleh karena itu, pendidikan merupakan hal yang sangat dianjurkan oleh Islam karena apabila pendidikan diabaikan atau tidak menjadi perhatian maka bahaya akan muncul di hadapan manusia dan sangat tidak dapat ditolerir akibatnya. Oleh karena itu secara tegas Al-Abrasyi mengatakan bahwa maksud dari pendidikan dan pengajaran bukanlah memenuhi otak anak didik dengan segala macam ilmu pengetahuan yang belum mereka ketahui, tetapi maksudnya adalah mendidik akhlak dan jiwa mereka, menanamkan rasa fadhilah (keutamaan), membiasakan mereka dengan kesopanan yang tinggi, mempersiapkan mereka menuju suatu kehidupan yang suci, ikhlas dan jujur. ${ }^{4}$ Dengan demikian, Islam sangat mementingkan pendidikan yang benar dan berkualitas sehingga akan terbentuk individu-individu yang beradab dan akhirnya akan memunculkan kehidupan sosial yang berakhlak.

Kenyataan sekarang umat Islam memang tertinggal jauh oleh masyarakat non muslim dan berada dalam lingkaran sosial ekonomi yang rendah. Sebagaimana yang

\footnotetext{
${ }^{1}$ Ellya Roza, “Aksara Arab-Melayu di Indonesia (Suatu Refleksi Historis)," Jurnal Sosial Budaya, Vol. 2, No. 1, (2005).

${ }^{2}$ Oman Faturrahman, "Filologi Plus: Metode dan Pendekatan," Paper pada Temu Peneliti Naskah Keagaman Puslitbang Lektur Keagamaan, Bukittinggi: 7-10 Juli 2010.

${ }^{3}$ Zakiah Drajat, Ilmu Pendidikan Islam (Jakarta: Bumi Aksara, 2012), 86.

${ }^{4}$ Al-Abrasyiy, Dasar-dasar Pokok Pendidikan Islam (Jakarta: Bulan Bintang, 2013), 15.
} 
dikatakan oleh John Kenneth Galberaith bahwa kemiskinan di dunia ini dialami oleh bagian terbesar adalah umat Islam. ${ }^{5}$ Fenomena tersebut juga terjadi di Indonesia yang mayoritas penduduknya menganut agama Islam meskipun secara geografis wilayah Indonesia yang terletak di garis katulistiwa memiliki sumber daya alam yang kaya dibanding negara-negara lainnya. Bahkan Indonesia termasuk dalam kategori negaranegara berkembang yang secara umum belum mampu meningkatkan kesejahteraan rakyatnya. Meskipun institusi-institusi pendidikan di Indonesia saat ini memiliki kualitas dan fasilitas, namun institusi-institusi tersebut masih belum memproduksi individu-individu yang beradab. Hal ini dikarenakan visi dan misi pendidikan tidak mengarah kepada terbentuknya manusia yang beradab akan tetapi mengarah kepada bisnis yang menggiurkan.

Apabila melihat pada masa lalu, masyarakat muslim telah berjaya memunculkan aksara Arab-Melayu. Aksara ini digunakan oleh tokoh-tokoh masyarakat dan ulama untuk menuliskan ide pemikirannya dan juga untuk menyampaikan pesan, amanat, petuah, pepatah petitih, pelajaran dan lain sebagainya. Untuk itulah dalam kesempatan ini diajak semua para ahli untuk melirikkan pandangan kepada warisan budaya bangsa yang diproduksi secara manual dan sangat sederhana sekali namun memiliki makna yang luas.

Namun dikarenakan kehadiran teknologi yang canggih dan modern pada saat sekarang ini, maka naskah tidak luput dari teknologi tersebut. Naskah dapat dikemas oleh berbagai alat teknologi sehingga dapat diakses dengan mudah jika diperlukan. Oleh karena itu, naskah Melayu yang telah mengalami digitalisasi dapat dimanfaatkan sebagai sumber keilmuan, baik penelitian lapangan maupun penelitian kepustakaan. Artinya naskah Melayu dalam bentuk digital dapat dengan mudah diperoleh dan diakses sebagai salah satu sumber kajian sehingga akan mampu memberikan sumbangsih terhadap perkembangan pendidikan Islam.

Proses tulisan ini memerlukan metode. Metode mengandung makna cara melakukan sesuatu. ${ }^{6}$ Dari segi metodologi, tulisan ini merupakan kajian terhadap peninggalan sejarah dan budaya dengan melibatkan naskah Melayu. Kajian naskah

${ }^{5}$ John Kenmeth Galberaith, Hakikat Kemiskinan Massa, Terj. Tom Anwar (Jakarta: PN Sinar Harapan, 1983), 13.

${ }^{6}$ Tim Penyusun, Kamus Besar Bahasa Indonesia (Jakarta: Pusat Bahasa Indonesia, 2008), 1030. 
mengarah kepada aspek filologi, ${ }^{7}$ (taḥqīq an-nuṣuṣs) dengan menggunakan metode deskriptif kualitatif. ${ }^{8}$ Metode deskriptif adalah memberi sesuatu uraian dan gambaran secara rinci atau menggambarkan realitas yang kompleks sehingga penjelasan dan analisis interpretasinya tercapai. Sedangkan metode kualitatif yang dimaksud adalah upaya memahami sedemikian rupa dengan tidak memerlukan kuantifikasi. Artinya kajian ini melibatkan naskah sebagai sumbernya. Kajian naskah termasuk ke dalam kajian dengan pendekatan kualitatif yang sering dikaitkan dengan analisis dan interpretasi ${ }^{9}$ yang akhirnya memfokuskan kepada content analysis. ${ }^{10}$ Untuk menjaring data dalam penelitian ini dilaksanakan dengan pendekatan Information and Communication Technologies (ICT) karena Naskah Melayu Digital telah mendapat sentuhan teknologi.

\section{B. Pendidikan Islam}

Kajian pendidikan Islam sebenarnya bukan sesuatu yang baru karena telah banyak buku yang disusun guna merekam kembali semua hal yang berkaitan dengan pendidikan Islam tersebut. Selain itu, sebagian kalangan mengatakan bahwa hal itu ada hubungannya dengan kebangkitan Islam di mana ketika dunia mengalami kemerosotan moral yang sangat mengkhawatirkan akibat dari beratnya paradigma pendidikan yang berkiblat kepada konsepsi pendidikan barat, maka orang-orang mulai mencari konsepsi alternatif. Konsepsi pendidikan Islam dipandang sebagai salah satu konsep alternatif. Dengan demikian. maka bermunculanlah kajian-kajian tentang pendidikan Islam. Namun pengertian secara komprehensif perlu dikemukakan juga guna diperoleh

${ }^{7}$ Ismail Yahya, Moh. Abdul Kholiq Hasan dan Farkhan, Penerjemahan Manuskrip Masãil atTa'lim ke dalam Aksara Pegon Pada Abad ke-17 M. (Surakarta: IAIN Surakarta Press bekerjasama dengan Pusat Studi Manuskrip Islam (PUSMI) dan Direktorat PTKI Kementerian Agama RI, 2018), 10. Baca Oman Fathurrahman, Filologi Indonesia: Teori dan Metode (Jakarta: Prenadamedia, 2015), 69-97; Oman Fathurrahman, dkk, Filologi dan Islam Indonesia (Jakarta: Balitbang dan Diklat Keagamaan Depag RI, 2010). Baca juga Hasan Muarif Ambary, "Kontribusi Filologi, Sejarah dan Arkeologi bagi Pengembangan Kebudayaan Indonesia," Jurnal Lektur Keagamaan, Vol. 3, No. 1 (2005): 90-103; Pradotokusumo, Kakawin Gajah Mada: Sebuah Karya Sastra Abad ke-20 Suntingan Naskah Serta Telaah Struktur Tokoh dan Hubungan Antar Teks (Bandung: Binacipta,1986).

${ }^{8}$ Mohd. Nazir, Metode Penelitian (Jakarta: Bina Aksara, 2000), 63. Baca juga Hartono, Metodologi Penelitian (Pekanbaru: Zanafa Publising, 2011); Vredenbergt, Metode dan Teknik Penelitian (Jakarta: Gramedia, 2002).

${ }^{9}$ Lexy J. Moeloeng, Metode Penelitian Kualitatif (Bandung: Rosdakarya, 1997), 4-5. Baca Noeng Muhadjir, Metodologi Penelitian Kualitatif (Yogyakarta: Rake Sarasian, 2000); Vredenbergt, Metode...; Mohd. Nazir, Metode Penelitian ...; Hartono, Metodologi Penelitian ...

${ }^{10}$ Suwardi Endaswara, Metode, Teori, Teknik Penelitian Kebudayaan (Yogyakarta: Pustaka Widyataman, 2006), 11. Baca juga Sugiyono, Metode Penelitian Kuantitatif Kualitatif dan $R \& D$ (Bandung: Alfabeta, 2013). 
keseragaman pemahaman tentang pendidikan Islam itu sendiri. Sebagaimana yang dikatakan oleh Munzir Hitami bahwa persoalan pendidikan pada umumnya dan pendidikan Islam khususnya pada hakikatnya adalah persoalan yang berhubungan langsung dengan kehidupan manusia dan mengalami perubahan serta perkembangan sesuai dengan kehidupan tersebut, baik secara teori maupun konsep operasionalnya. Oleh karena itu diskursus pendidikan tidak akan pernah mati dan senantiasa menarik dan penting diperbincangkan. ${ }^{11}$

Menurut Yusuf Hamiri, pendidikan Islam adalah usaha sadar untuk menyiapkan siswa dalam meyakini,memahami, menghayati, dan mengamalkan agama Islam melalui kegiatan bimbingan, pengarahan atau latihan dengan memperhatikan agama lain dalam hubungan kesatuan nasional. ${ }^{12}$ Sementara itu Al-Syaibaniy berpendapat bahwa pendidikan Islam adalah proses perubahan tingkah laku individu pada kehidupan peribadi, masyarakat dan alam sekitarnya dengan cara pengajaran sebagai suatu aktifitas asasi dan sebagai profesi di antara profesi-profesi asasi dalam masyarakat. ${ }^{13}$ Sedangkan menurut Ahmad Marimba, pendidikan Islam adalah bimbingan jasmani dan rohani berdasarkan hukum-hukum agama Islam menuju kepada terbentuknya kepribadian utama menurut ukuran-ukuran Islam. ${ }^{14}$ Di dalam GBPP PAI sekolah umum, yang dikutip oleh Akmal Hawi, dijelaskan bahwa Pendidikan Agama Islam (PAI) adalah usaha sadar untuk menyiapkan siswa dalam meyakini, memahami,menghayati dan mengamalkan agama Islam melalui kegiatan bimbingan, pengajaran, dan latihan dengan memperhatikan tuntutan untuk menghormati agama lain dalam hubungan kerukunan antar umat beragama dalam masyarakat untuk mewujudkan persatuan nasional. Dengan demikian dapat dipahami bahwa pendidikan Islam merupakan usaha sadar yang dilakukan pendidik dalam rangka mempersiapkan peserta didik untuk meyakini, memahami,dan mengamalkan ajaran Islam melalui kegiatan bimbingan,pengajaran atau pelatihan yang telah ditentukan untuk mencapai tujuan yang telah ditetapkan. ${ }^{15}$

\footnotetext{
${ }^{11}$ Munzir Hitami, Mengonsep Kembali Pendidikan Islam (Pekanbaru: Infinite Press. 2004), 1.

${ }^{12}$ Yusuf Hamiri dan Firdaus Basuni, Metodologi Pengajaran Agama Islam (Palembang: IAIN Raden Fatah Press, 2005), 20. 1979), 399.

${ }^{13}$ Al-Syaibaniy, Filsafat Pendidikan Islam, Terj. Hasan Langgulung (Jakarta: Bulan Bintang,

${ }^{14}$ Ahmad D. Marimba, Pengantar Filsafat Pendidikan Islam (Bandung: Alma'arif, 1999), 43

${ }^{15}$ Akmal Hawi, Kapita Selekta Pendidikan Islam (Palembang: IAIN Raden Fatah Press, 2005), 194.
} 
Oleh karena itu, pendidikan Islam merupakan usaha membimbing dan mengarahkan potensi hidup manusia berupa kemampuan-kemampuan dasar dan kemampuan belajar sehingga terjadi perubahan di dalam kehidupan pribadinya, baik sebagai makhluk individual maupun sebagai makhluk sosial serta hubungannya dengan alam sekitar.

\section{Naskah Melayu}

Naskah berarti (1) karangan; (2) lembaran; (3) rancangan. ${ }^{16}$ Didasari oleh pengertian tersebut dapatlah dipahami bahwa naskah itu salah satu peninggalan budaya yang terdiri dari lembaran-lembaran apakah kertas, daun atau sebagainya yang ditampilkan dalam bentuk karangan. Secara praktis dapat dikatakan bahwa naskah adalah semua peninggalan masyarakat masa lampau yang ditulis dengan tulisan tangan dan ditulis di atas kertas, pelepah, lontar, daun, kulit kayu, daluwang, bambu dan sebagainya. Artinya naskah adalah salah satu peninggalan dalam bentuk tulisan yang belum disentuh oleh peralatan modern seperti mesin cetak, alat elektronik dan teknologi. Oleh karena itu, naskah merupakan dokumen bangsa yang menarik bagi peneliti untuk dijadikan sumber kajian karena dalam naskah dapat diperoleh berbagai macam bentuk intelektual masyarakat masa lalu.

Dikarenakan dominannya ras Melayu di wilayah Nusantara menjadikan hanya memiliki banyak naskah yang disebut dengan naskah Melayu. Istilah atau penggunaan perkataan Melayu hari ini mempunyai tiga pengertian meskipun dalam konteks yang berbeda. ${ }^{17}$ Pengertian Melayu pertama digunakan di Indonesia yaitu Melayu merupakan salah satu dari beberapa suku atau etnik seperti orang-orang Jawa, Aceh, Bugis, Makasar, Bali, Mandailing, Batak, Kerinci, Banjar, Lampung, Minangkabau, Boyan, Madura, Menado, Toraja dan sebagainya.

Pengertian Melayu kedua digunakan di Malaysia, di mana gerakan nasionalisme Melayu pada tahun-tahun 30-an dan 40-an telah meleburkan pemisahan antara sukusuku atau etnik ini dengan menjadikan mereka semua sebagai Bangsa Melayu atau $a$ Malay Nation yang termaktub dalam Perlembagaan Malaysia yaitu mereka yang

\footnotetext{
${ }^{16}$ Tim Penyusun, Kamus Besar Bahasa Indonesia (Jakarta: Departemen Pendidikan dan Kebudayaan RI, 2008).

${ }^{17}$ Ellya Roza, "Internalisasi Nilai Islam dan Tamadun Melayu terhadap Perilaku Sosial Orang Melayu Riau,” Jurnal Toleransi:Media Komunikasi Umat Beragama, Vol. 6, No.1 (2014): 16-35
} 
mempunyai tiga ciri-ciri utama, yaitu (1) yang bertutur dan menjadikan bahasa Melayu sebagai bahasa pertama; (2) beragama Islam; dan (3) berpegang kepada adat resam yang lazimnya diamalkan oleh orang-orang Melayu. Hal ini juga berlaku bagi konsep Melayu di Riau sebagaimana yang disebutkan oleh Hamidi bahwa penduduk di daerah ini (Melayu) mempunyai tiga identitas: (1) beragama Islam; (2) berbahasa Melayu; (3) mempunyai kesamaan dalam adat dan tradisi. ${ }^{18}$

Pengertian Melayu ketiga membawa maksud kepada satu kelompok bangsa yang besar atau ras (Inggris 'race') atau 'rumpun bangsa' (a racial stock). Istilah tersebut digunakan dalam bidang antropologi dan sosiolinguistik dan juga digunakan oleh UNESCO dengan merujuk kepada penduduk asli di Semenanjung dan Gugusan PulauPulau Melayu yang kini lebih dikenal sebagai Alam Melayu atau the Malay World. Makna tersebut lebih kepada konsepsi budaya yang tidak menjadikan agama Islam sebagai salah satu syarat sah Melayu seperti orang-orang Filipina, etnik Batak atau Bali dan penduduk asli di Pulau Taiwan dikategorikan sebagai 'rumpun Melayu.' Salah satu unsur persamaan mereka ialah bertutur dalam bahasa dari cabang atau rumpun bahasa induk Austronesia atau Melayu-Polinesia. Artinya saudara terdekat kepada rumpun atau ras Melayu itu ialah bangsa Polinesia yang tersebar secara meluas di Kepulauan Pasifik sampai ke Pulau Hawai, New Zealand dipercayai berasal dari Alam Melayu dan mempunyai akar bahasa yang sama yaitu Austronesia.

Adapun Melayu sebagai sebuah wilayah yang mempunyai penduduk meliputi penduduk yang mendiami Kepulauan Indonesia, Tanah Semenanjung sampai kepada penduduk di Kepulauan Polinesia. Mereka ini mempunyai kesamaan dalam bahasa dan budaya. Oleh kerana itu. mereka disebut sebagai bangsa Melayu-Polinesia. ${ }^{19}$

Di daerah-daerah yang berada di kawasan sebagaimana yang disebutkan di atas, naskah kebanyakan berbahasa Melayu. Wijk mengatakan bahwa bahasa Melayu digunakan sebagai bahasa perdagangan antar pulau dan akhirnya menjadi bahasa perantara antar kepulauan Nusantara. ${ }^{20}$ Sedangkan menurut Hussein, Bahasa Melayu pada masa kejayaan Kerajaan Melayu di Malaka, Pasai dan Aceh digunakan untuk

\footnotetext{
${ }^{18}$ U.U. Hamidi, Islam dan Masyarakat Melayu di Riau (Pekanbaru: UIR Press, 1999), 169.

${ }^{19}$ Ibid., 23. Baca juga Hamka, Sejarah Umat Islam, Jilid II (Jakarta: Bulan Bintang, 2012); Muhammad Yusoff Hashim, Pensejarahan Melayu: Kajian tentang Tradisi Sejarah Melayu Nusantara (Kuala Lumpur: Dewan Bahasa dan Pustaka); Harun Mat Piah, "Tamadun Melayu sebagai Asas Kebudayaan Kebangsaan, Suatu Tinjauan dan Justifikasi,” dalam Ismail Hussein (penyelenggara), Tamadun Melayu, Jilid II (Kuala Lumpur: Dewan Bahasa dan Pustaka, 1989).

${ }^{20}$ D. Gerth Van Wijk, Tata Bahasa Melayu, Terj. T.W. Kamil (Jakarta: Djambatan, 1985), 7.
} 
menyusun dan menggubah karya sastra. Karya sastra yang dihasilkan di istana umumnya berupa sastra tulis dan yang tergolong sastra rakyat berupa sastra lisan. ${ }^{21}$ Menurut Teeuw yang dikutip oleh Harimukti pemakaian Bahasa Melayu sebenarnya lebih luas lagi yaitu semua bahasa yang dahulu atau kini dipakai di berbagai bagian Malaya, Sumatera, Kalimantan, Jakarta dan Irian Jaya. namun Bahasa Melayu yang lebih dikenal biasanya disebut Bahasa Melayu Riau atau Bahasa Melayu Johor karena tempat tersebut merupakan bekas kerajaan yaitu Kerajaan Riau Lingga dan Kesultanan Johor. $^{22}$

Puji Astuti berpendapat bahwa aksara Arab yang berbahasa Arab sudah ada di Nusantara sejak abad ke-3 H. Hal ini dapat dilihat pada ukiran batu nisan di Kedah (Langgar). Kemudian juga terdapat beberapa prasasti lain dalam abad ke-5 H seperti di Vietnam, Pahang, Bandar Sri Begawan dan Brunei Darussalam. ${ }^{23}$ Berawal dari sini, maka terjadi perpaduan antara aksara Arab dengan Bahasa Melayu yang digunakan untuk menuliskan ajaran-ajaran yang disampaikan oleh mubaligh kepada pengikutnya. Dikarenakan pengikut atau masyarakat tempatan tidak bisa berbahasa Arab, maka mereka mengupayakan untuk menggabungkannya. Yang dipakai untuk menulis adalah aksara Arab, sedangkan bahasa yang digunakan adalah Bahasa Melayu sehingga terjadi perpaduan antara huruf Arab dengan bahasa Melayu yang akhirnya disebut dengan aksara Arab-Melayu. ${ }^{24}$ Artinya aksara Arab-Melayu adalah aksara Arab yang berkolaborasi dengan bahasa Melayu dengan beberapa penyesuaian dan tambahan huruf. Dengan demikian dapat dikatakan aksara Arab-Melayu merupakan campuran aksara Arab yang terdiri dari 29 aksara (alif sampai ya) dan lima aksara yang diciptakan oleh suku bangsa Melayu sendiri. Penambahan aksara tersebut digunakan untuk keperluan fonem Melayu yang lebih banyak dibandingkan dengan fonem Arab. Bentuk tempat aksaranya sama dengan aksara Arab namun ditambahkan dengan beberapa titik sebagai pembeda bunyi dan fungsinya. ${ }^{25}$

\footnotetext{
${ }^{21}$ Ismail Hussein, op. cit ., h.10

${ }^{22}$ Harimukti Kridalaksana, Masa Lampau Bahasa Indonesia: Sebuah Bunga Rampai (Yogyakarta: Sinar Harapan, 1991), 11.

${ }^{23}$ Titik Pudjiastuti (Ed.), Filologia Nusantara (Jakarta: Pustaka Jaya, 1997), 139.

${ }^{24}$ Ellya Roza, "Aksara Arab-Melayu di Nusantara dan Sumbangsihnya dalam Pengembangan Khazanah Intelektual,” Tsaqafah Jurnal Peradaban Islam, Vol. 13, No.1 (2017): 178.

${ }^{25}$ Ellya Roza, "Sejarah Keberadaan Aksara Arab-Melayu di Nusantara dan Peranannya untuk Membaca Khazanah Intelektual Naskah-Naskah Melayu. Paper yang disampaikan pada acara Seminar
} 
Dengan adanya aksara Arab-Melayu yang telah dirumuskan oleh local genius Melayu, maka ulama, kyai dan tokoh-tokoh masyarakat pada zamannya menuliskan ide pemikirannya, pesan, amanat, petuah, pepatah dan petitih, pelajaran, dan lain sebagainya dengan aksara tersebut. ${ }^{26}$ Untuk itulah dalam kesempatan ini diajak semua para ahli untuk melirikkan pandangan kepada warisan budaya bangsa yang diproduksi secara manual dan sangat sederhana sekali namun memiliki makna yang luas.

Pada dasarnya naskah-naskah lama itu merupakan kesaksian tertulis atau dokumen budaya yang berisi berbagai data dan informasi tentang pikiran. perasaan dan pengetahuan dari suatu bangsa atau kelompok sosial budaya tertentu yang sekaligus juga sebagai unsur budaya yang erat kaitannya dengan kehidupan sosial masyarakat yang menyusunnya. ${ }^{27}$ Oleh karena itu warisan budaya tersebut perlu ditelaah, sekurangkurangnya mempelajarinya dengan baik dan menjadikan hasil-hasil kajian itu milik bersama bagi seluruh bangsa.

Meskipun peninggalan naskah Melayu termasuk paling besar jumlahnya namun jumlah yang pasti belum diketahui secara tepat dan juga belum ada kesepakatan antara filolog mengenai jumlah naskah Melayu. Artinya jumlah naskah Melayu tidak dapat disebutkan angkanya sebab tidak terpantaunya naskah yang ada di daerah-daerah yang menjadi milik seseorang, milik suku, milik kaum dan sebagainya sehingga keberadaan naskah yang di daerah sangat jauh dari jangkauan peneliti dan pengamat naskah. Selain itu pelacakan dan penelusuran naskah Melayu masih berlanjut dilakukan oleh peminat naskah sehingga naskah Melayu jumlahnya bertambah bersamaan dengan bertambahnya waktu. ${ }^{28}$ Meskipun demikian beberapa ilmuwan mencoba juga untuk mengklasifikasikannya seperti Chambert-Loir dan Faturrahman berpendapat bahwa jumlah naskah Melayu yang belum disunting dan diterbitkan sesungguhnya jauh lebih besar dari pada

Internasional yang ditaja oleh Himpunan Mahasiswa Jurusan Pendidikan Bahasa Arab UIN Suska Riau Jumat 17 April 2015 di Islamic Center UIN Suska Riau.

${ }^{26}$ Ellya Roza, “Aksara Arab-Melayu di Nusantara...," 179.

${ }^{27}$ Edi S. Ekadjati, Naskah Sunda (Bandung: Lembaga Penelitian Unpad bekerjasama dengan The Toyota Foundation, 1988), 1. Oman Faturrahman, "Filologi Plus: Metode dan Pendekatan," Paper pada Temu Peneliti Naskah Keagaman Puslitbang Lektur Keagamaan, Bukittinggi: 7-10 Juli 2010.

${ }^{28}$ Ellya Roza, Naskah Melayu (Pekanbaru: Yayasan Pusaka, 2010), 23. 
naskah yang sudah disunting dan diterbitkan. baik yang tersimpan di dalam maupun di luar negeri. ${ }^{29}$

Menggali warisan nenek moyang yang agung nilainya itu perlu dalam rangka membina dan mengembangkan pola pikir masyarakat terutama dalam bidang pendidikan Islam sehingga dapat dikatakan bahwa naskah Melayu adalah salah satu sumber ilmu pengetahuan bagi setiap cabang ilmu karena naskah-naskah itu akan memberikan informasi masyarakat masanya kepada masyarakat sekarang.

\section{Naskah Melayu Digital}

Digitalisasi naskah Melayu adalah proses pengalihan naskah Melayu dari bentuk aslinya ke dalam bentuk digital atau menyalinnya dengan melakukan scanning (dengan scanner) atau memfotonya dengan kamera digital. Digitalisasi naskah perlu dilakukan agar isi kandungan dari naskah tersebut tetap terjaga jika sewaktu-waktu fisik naskah sudah tidak dapat dipertahankan lagi. Pilihan inilah yang paling tepat dilakukan saat ini yakni pemanfaatan teknologi digital, baik berbentuk kamera maupun scanner karena digitalisasi mampu membuat salinan atau cadangan naskah dari aslinya yang sudah tidak dapat digunakan lagi.

Digitalisasi naskah merupakan salah satu upaya memperpanjang usia naskah. Digitalisasi naskah memainkan peran penting dalam upaya pelestarian tradisi intelektual. Dapat dibayangkan kerugian yang ditanggung oleh generasi sekarang seandainya naskah Melayu sebagai warisan kultural dan intelektual itu rusak sementara pengkajian si naskah belum dilakukan. Oleh karena itu, program IT dapat dimanfaatkan terhadap naskah Melayu. Dengan demikian dapat dikatakan bahwa untuk melestarikan asset kultural dan intelektual tersebut, maka digitalisasi naskah merupakan salah satu alternative solusinya.

Sebelum era digital, telah dilakukan pengalihmediaan terhadap naskah Melayu oleh Ford Foundation dalam bentuk media microfilm yakni sebuah media yang pada era itu sangat luar biasa keunggulannya. Misalnya naskah Melayu yang tersimpan di Pulau Penyengat di bawah naungan Yayasan Indera Sakti telah dilakukan alihmedia microfilm oleh Yan van der Putten seorang ahli pernaskahan yang berbangsa Belanda. Demikian

\footnotetext{
${ }^{29}$ Chambert-Loir dan Faturrahman, Panduan Koleksi Naskah-naskah Nusantara (Jakarta: Yayasan Obor Indonesia, 1999), 1.
} 
juga naskah-naskah lainnya telah dilakukan alihmedia tersebut oleh berbagai perpustakaan, baik di dalam negeri maupun di luar negeri.

Namun dengan kemajuan teknologi yang semakin cangkih dan hebat, maka naskah Melayu tidak luput dari teknologi tersebut sehingga naskah Melayu mengalami perubahan dalam hal penyimpanannya. Sebelum adanya teknologi, naskah Melayu hanya disimpan ditempat penyimpanan berupa museum atau tempat lainnya secara sederhana, baik yang dikelola pemerintah maupun yang dikelola secara mandiri. Penyimpanan naskah Melayu dengan cara sederhana bukan tidak mungkin mengalami kegagalan terhadap fisik naskah karena terbatasnya ketahanan naskah. Oleh karena itu dengan kemajuan teknologi sekarang ini, maka naskah Melayu juga mengalami kemajuan dalam hal penyimpanan. Sekarang naskah Melayu dapat disimpan dengan cara digital melalui IT yang sedang marak berkembang saat ini. Artinya, Digitalisasi naskah Melayu merupakan sebuah perubahan ke arah pembaharuan terhadap penyimpanan. Dengan demikian, kepunahan naskah menjadi teratasi sebab dapat disimpan secara teknologi sehingga kekhawatiran terhadap kehancuran naskah tidak menjadi kenyataan.

Sebenarnya digitalisasi naskah termasuk naskah Melayu semakin praktis pekerjaannya yakni dengan menggunakan jenis kamera tertentu dengan tipe yang dapat menghasilkan gambar atau foto dengan tingkat piksel tinggi saja sudah cukup. Foto naskah Melayu dapat dibaca jika di-zoom-kan. Kemudian kamera tersebut dihubungkan ke perangkat komputer atau laptop yang sudah diinstall perangkat lunak yang kompatibel untuk mengolah gambar yang diambil. Hasil dari pendigitalan dengan kamera berupa gambar dengan format RAW (format foto 'mentah') yang dapat dikonversi ke bentuk JPEG (Joint Photographic Experts Group) atau TIFF (Tagged Image File Format). Untuk koleksi perpustakaan, format yang dipakai adalah TIFF. Namun untuk konsumsi awam seperti peng-upload-an ke portal dunia maya menggunakan format JPEG karena piksel dan ukuran yang kecil. Hasil pendigitalan dengan menggunakan scanner berupa gambar dengan format yang biasanya adalah JPEG. Kemudian dengan perangkat lunak tertentu untuk di-edit. ${ }^{30}$

Digitalisasi terhadap naskah Melayu sebenarnya dapat dilakukan secara sederhana yakni dengan menggunakan kamera. Kamera digunakan untuk memotret

\footnotetext{
${ }^{30}$ Ivan Sudirman, "Perkembangan Hardware Komputer,” diunduh di www.ilmukomputer.com
} 
naskah dan dilakukan sama dengan pemotretan benda lainnya. Setelah naskah dipotret lembar demi lembarnya atau halaman demi halaman, maka gambar naskah disimpan di dalam compac disk $(C D)$ dengan cara mentransfer melalui alat yang telah disediakan. Dengan demikian gambar naskah tersimpan dengan baik

Oleh karena itu, naskah Melayu digital ini sangat jelas manfaatnya, karena dapat mengkaji teks tanpa menghadirkan naskah aslinya. Selain untuk menjaga dari kepunahan, digitalisasi juga berguna untuk memudahkan proses penggandaan karena penggandaan seperti fotokopi terhadap naskah aslinya sudah barang tentu tidak bisa dilakukan karena naskah sudah lapuk. Apabila dipegang oleh tangan-tangan manusia dan dibuka-buka untuk mengkopinya niscaya fisik naskah semakin rusak sehingga kehancuran naskah semakin dekat.

\section{E. Naskah Melayu Digital sebagai Sebuah Inovasi Kajian Pendidikan Islam}

Naskah Melayu mengandung isi yang meliputi pelbagai bidang dan sangat beraneka ragam. Berdasarkan itu, maka Naskah Melayu dapat dijadikan sebagai salah satu sumber kajian mengingat banyaknya kandungan pesan-pesan yang ada di dalamnya. Hal tersebut akan bermanfaat apabila dilakukan kajian dan analisis terhadap naskah-naskah yang telah dihasilkan oleh sesuatu bangsa sehingga pada masanya naskah akan berbicara dengan sendirinya menyampaikan informasi jika dibaca oleh ahlinya.

Untuk setakat ini naskah yang digunakan hanyalah naskah yang masih manual yang sangat susah untuk dibaca dan dipahami kandungan isinya. Pada hal naskah Melayu sangat penting untuk dikaji karena naskah-naskah tersebut bukan saja memiliki suatu gambaran masa lampau, melainkan merupakan sumber pengetahuan yang dapat membantu masyarakat dalam usaha mempelajari, mengetahui dan mengerti akan sejarah perkembangan intelektual bangsa. Pandangan tersebut sejalan dengan pendapat Keesing ${ }^{31}$ bahwa pola pandangan, sikap dan prilaku manusia di berbagai belahan bumi dapat diamati, dipelajari dan diungkapkan melalui kebudayaannya. Melalui media kebudayaan itulah manusia membina interaksi dengan sesamanya dan

\footnotetext{
${ }^{31}$ Keesing, Antropologi Budaya: Suatu Perpektif Kontemporer, Terj. Samuel Gunawan (Jakarta: Gramedia,1991), 94.
} 
alam serta mewariskan nilai-nilai yang dianggap bermanfaat untuk kelangsungan hidup mereka dari generasi ke generasi berikutnya.

Sejalan dengan proses pendigitalan biasanya dilakukan juga proses pendeskripsian naskah. Proses pendeskripsian ini bertujuan untuk membuat katalog, namun tak hanya sebatas pada fisik naskah saja, tapi juga ringkasan isi naskah.

Digitalisasi memiliki manfaat, di antaranya (1) untuk mengamankan isi naskah dari kepunahan agar generasi seterusnya tetap mendapatkan informasi dari ilmu-ilmu yang terkandung dari naskah tersebut; (2) mudah digandakan berkali-kali untuk dijadikan cadangan (backup) data; (3) mudah untuk digali informasinya oleh para peneliti jika di-upload ke sebuah alamat web; (4) dapat dijadikan sebagai obyek promosi terhadap kekayaan bangsa.

Melalui cara digital, diharapkan naskah dapat dilestarikan sehingga meskipun naskah sudah lapuk akan tetapi naskah masih dapat digunakan oleh berbagai kalangan sesuai dengan keperluan pengembangan ilmu pengetahuan. Apabila hendak digunakan untuk keperluan pengembangan ilmu pengetahuan seperti linguistik, sosiologi, antropologi, sastra, sejarah, agama, pendidikan dan lainnya maka dapat melakukan print out terhadap gambar naskah yang telah tersimpan di dalamnya atau dapat dibesarkan dengan mengklik sesuai petunjuk. Kemudian teks dapat dibaca sehingga kandungan isi naskah dapat di analisis sesuai dengan bidang ilmu yang diinginkan.

Kandungan isi naskah meliputi berbagai bidang dan sangat beraneka ragam. Namun secara umum naskah-naskah di Nusantara dapat dikelompokkan paling tidak ke dalam empat kategori yaitu (1) naskah-naskah yang berisi teks sejarah; (2) naskahnaskah keagamaan; (3) naskah-naskah sains; (4) naskah-naskah kesusastraan. ${ }^{32}$ Di antara kandungan isi naskah tersebut, maka naskah-naskah yang berisi teks keagamaan merupakan naskah yang paling banyak jumlahnya karena akibat dari Islamisasi di Nusantara. Oleh karena itu, sangat menarik untuk dikaji secara serius. Hal ini disebabkan karena kandungan naskah dapat menambah informasi keagamaan terutama bidang pendidikan Islam.

Bukan rahasia lagi bahwa pada abad ke-14 dan 15 ketika penyebaran agama Islam sedang berlangsung, yang menjadi bahasa pendukung di Nusantara adalah bahasa Melayu. Ini tentu tidak mengherankan apabila disadari bahwa bahasa Melayu sudah

\footnotetext{
${ }^{32}$ Emuch Hermansoemantri, Identifikasi Naskah (Bandung: FASA UNPAD, 1986), 6.
} 
lama menjadi lingua franca di kawasan ini. Dapat diperhatikan bahwa ketika pada saat awal aksara Arab sudah di adopsi oleh bahasa Melayu dan mengungguli huruf abjad India, maka di seluruh Kepulauan Nusantara, kata dan ungkapan Melayu yang ada kaitannya dengan ke-Islaman diterima ke dalam bahasa pribumi. Oleh karena itu, hasil karya sastra Melayu klasik memiliki khazanah Islam yang luas. ${ }^{33}$ Menurut Ikram, aksara Arab-Melayu digunakan oleh masyarakat Melayu untuk menuliskan wacana yang berbahasa Melayu yakni bahasa yang sudah dipakai pada zaman Kerajaan Sriwijaya sebagai bahasa resmi, tidak terbatas dalam bidang administrasi tetapi juga sebagai bahasa pengantar dalam kegiatan keagamaan. ${ }^{34}$

Selain itu, keseluruhan pikiran yang diungkapkan dalam naskah tersebut dinaungi oleh kehidupan dan keagamaan masyarakat yang hidup pada masa itu. Artinya isi naskah itu mencakup rentangan waktu yang luas tentang kehidupan spritual nenek moyang serta memberikan gambaran yang memadai tentang alam pikiran dan lingkungan hidupnya.

Oleh karena itu, urgensi naskah Melayu digital bagi masyarakat secara umum dan ilmuwan khususnya amat sangat membantu bagi pengembangan ilmu pengetahuan. Dengan naskah Melayu digital akan mempermudah peminat naskah untuk memperoleh tanpa menghadirkan naskah aslinya. Demikian juga akan mempermudah pembaca ketika membaca teks naskah karena dapat di-zoom-kan sehingga kata-kata yang kurang jelas menjadi jelas. Hal ini tentu saja naskah Melayu digital berkontribusi besar bagi peneliti yang memanfaatkan naskah sebagai sumber kajiannya. Oleh karena itu, sekali lagi disampaikan bahwa naskah Melayu digital yang mengandung nilai pendidikan Islam dapat digunakan sebagai sumber kajian keilmuan mengingat kandungan teksnya memiliki relevansi dengan keadaan sekarang ini yang penuh dengan dekadensi moral. Naskah Melayu yang mengandung pendidikan Islam berisikan ajaran moral untuk menjalani kehidupan di dunia dan kehidupan di akhirat, demikian juga dalam kehidupan berbangsa dan bernegara sehingga nantinya akan tercipta suasana baldatun thayyibatun wa rabbun ghafur.

Untuk mengetahui keberadaan naskah yang mengandung keagamaan Islam dapat dilihat pada daftar yang tertera pada katalogus naskah yang telah disusun oleh

\footnotetext{
${ }^{33}$ Ellya Roza, “Aksara Arab-Melayu di Nusantara...," 178.

${ }^{34}$ Achdiati Ikram, "Sastra Lama sebagai Penunjang Pengembangan Sastra Modern," Majalah Bahasa dan Sastra, No . 2 (1976), 2.
} 
Departeman Agama Pusat Jakarta, yakni Katalog Naskah Kuno Yang Bernafaskan Islam di Indonesia I oleh Tim Penyusun yang terdiri dari Hj. Musda Mulia, H. Rosehan Anwar dan H. E. Badri Yunardi. Diterbitkan oleh Badan Penelitian dan Pengembangan Agama, Departeman Agama RI Jakarta setebal 273 halaman. Dalam katalog tersebut, naskah yang berhasil dihimpun dan dikumpulkan sebanyak 368 naskah yang berasal dari 8 daerah, yaitu (1) Aceh: no.1-119=119 naskah; (2) Sumatera Utara : no. 120 160 berjumlah 40 naskah; (3) Riau: no. 161 - 207 berjumlah 146 naskah; (4) Jambi: no. 208 - 229 berjumlah 21 naskah; (5) Sumatera Barat : no. 230 - 260 berjumlah 30 naskah; (6) Sumatera Selatan : no. 261 - 303 berjumlah 42 naskah; (7) Lampung: no. 304 - 315 berjumlah 11 naskah; (8) Sulawesi Selatan : no. 316 - 368 berjumlah 52 naskah. Selanjutnya menyusul pula Katalog Naskah Kuno Yang Bernafaskan Islam di Indonesia II yang disusun oleh tim yang sama, setebal 256 halaman. Naskah yang berhasil dihimpun dan dikumpulkan sebanyak 391 naskah yang berasal dari 6 daerah yaitu (1) Jawa Barat : no. 369-495 berjumlah 126 naskah: (2) Kalimantan Selatan : no. 496 - 511 berjumlah 15 naskah; (3) Jawa Timur : no. 512 - 582 berjumlah 70 naskah; (4) DIY : no. 583 - 661 berjumlah 78 naskah; (5) Maluku : no. 662 - 695 berjumlah 33 naskah; (6) NTB : no. 696 - 759 berjumlah 63 naskah.

Berdasarkan katalog berbagai naskah yang ada terutama naskah keagamaan, apakah tidak mungkin dijadikan sebagai sumber kajian pendidikan Islam. Hal ini tentunya terpulang kepada pengkaji pendidikan Islam yang ada di seluruh Indonesia untuk memanfaatkan naskah Melayu digital sebagai sumber kajiannya.

Sekedar untuk diketahui bahwa beberapa pengkaji yang telah mengusahakan digitalisasi naskah di antaranya Jeje Abd Rojak, Koordinator Progam Digitalisasi Naskah-naskah Pesantren MIPES (2007); Fakhriati, Koordinator Program Digitalisasi naskah Koleksi Masyarakat Pidie, Aceh (2008); Bahren S.S. Koordinator Fotografi Program Digitalisasi Naskah Surau Minangkabau (2006) dan masih banyak yang lainnya.

Sampai setakat ini beberapa lembaga penyimpanan naskah Melayu telah melakukan upaya penyelamatan terhadap naskah Melayu yang ada di tempatnya. Di antaranya Propinsi Nangroe Aceh Darussalam yang telah melakukan proyek digitalisasi terhadap naskah Melayu, di mana kegiatan tersebut terselenggara berkat sinergi antara Museum Negeri Propinsi D.I. Aceh Darussalam, Museum Ali Hasjmy (YPAH) dan 
Pusat Kajian Pendidikan dan Masyarakat (PKPM) Aceh yang bekerjasama dengan Institut Studi Islam-Universitas Leipzig Jerman. Dalam kegiatan digitalisasi tersebut sebanyak 510 judul kitab (dalam kondisi lengkap) telah selesai proses pendigitalannya. Sisanya berjumlah 1200 naskah masih dalam bentuk aslinya dan direncanakan juga akan dilakukan digitalisasinya. Berikut ini dapat disebutkan beberapa judul naskah Melayu keagamaan yang telah dilakukan pendigitalannya.

1. Syarabul Asyiqin karya Hamzah Fansuri

2. Asrarul 'Arifin karya Hamzah Fansuri

3. Safinatul Hukkam fi Talkhisil Khassam karya Syekh Jalaluddin bin Syekh Kamaluddin at-Tarusani

4. Nasihatul Muslimin wa Tazkiratul Mukminin fi Fazail Jihad fi Sabilillah karya Abdussamad al-Palembani

\section{Hikayat Perang Sabil}

6. Hikayat Aroe Asyura

Pada waktu yang berbeda Universitas Leipzieg Jerman melakukan kerjasama pula dengan Museum Sonobudoyo Yogyakarta dan melibatkan UIN Sunan Kalijaga sebagai pelaksana lokal. Digitalisasi naskah seperti ini sebelumnya sudah dilakukan di Cirebon dan Solo dengan bantuan tenaga lokal dari masing-masing perguruan tinggi. Untuk Yogyakarta terdapat tiga tempat yang dilakukan digitalisasi naskah yaitu Widya Pustaka Keraton, Balai Bahasa dan Museum Sonobudoyo. Semuanya sudah terlaksana dengan baik. Hasil utuh dari digitalisasi naskah tersebut bisa dinikmati di ruang perpustakaan Museum Sonobudoyo. Di museum tersebut sekitar 1400an naskah ditampilkan dengan sarana komputer sehingga tidak merusak atau mengganggu benda fisik dari naskah tersebut. Artinya ketika ingin membaca naskah, maka seseorang tidak perlu bersinggungan dengan fisiknya dan cukup melalui komputer yang tersedia di ruang baca naskah. Artinya naskah Melayu yang telah digital tersebut pasti di antaranya dapat digunakan sebagai sumber dalam kajian pendidikan Islam karena sebagian besar naskah tersebut beraksara Arab Melayu. Dengan demikian keberadaan naskah Melayu digital dapat dimanfaatkan oleh pembaca, peminat dan pengkaji naskah sehingga memudahkan dalam proses pengadaannya.

Selain yang disebutkan di atas, di Perpustakaan Nasional Jakarta juga telah tersedia naskah Melayu dalam bentuk digital. Naskah Melayu digital tersebut dapat 
diakses dengan mengunjungi laman web Perpusnas yang telah disediakan. Sedangkan di Riau, digitalisasi naskah Melayu telah dilakukan oleh Universitas Lancang Kuning yang bekerjasama dengan Museum Sang Nila Utama Pekanbaru.

Dengan jumlah yang telah disebutkan di atas, apakah tidak mungkin para pengkaji ilmu Pendidikan Agama Islam untuk memanfaatkan naskah Melayu digital sebagai sumber kajiannya selain al-Qur`an dan Hadis. Alangkah ruginya jika tidak mengabaikan peluang kajian dengan inovasi baru yakni dengan menggunakan naskah Melayu digital sebagai sumber kajian atau sumber penelitian, karena naskah Melayu digital terutama yang mengandung teks keagamaan sangat besar jumlahnya. Oleh karena itu, peluang besar jangan disia-siakan sehingga para pengkaji pendidikan Islam tidak kekurangan sumber data penelitian.

\section{F. Kesimpulan}

Al-Qur`an dan Hadis yang menjadi sumber utama dalam kajian pendidikan Islam, maka warisan budaya pun dapat dijadikan sebagai sumber kajian. Salah satu warisan budaya bangsa yang dapat dijadikan sebagai sumber kajian pendidikan Islam adalah naskah Melayu.

Naskah Melayu yang dimaksud untuk dijadikan sebagai sumber kajian pendidikan Islam adalah naskah Melayu digital. Artinya naskah Melayu yang dijadikan sumber kajian adalah naskah Melayu yang sudah disentuh oleh teknologi karenanya sangat mudah diperoleh melalui jaringan IT. Naskah Melayu digital selain sangat mudah diperoleh juga sangat memudahkan dalam hal penggandaannya sebagai sumber data kajian. Naskah Melayu digital telah banyak dilakukan oleh orang perorangan maupun lembaga atau yayasan penyimpanan bahkan pihak pemerintah juga telah melakukan digitalisasi naskah Melayu. Untuk memudahkan informasi tentang naskah Melayu dapat dilihat pada katalogus naskah Melayu yang telah disusun oleh tempat penyimpanannya.

Oleh karena itu, himbauan bagi para pengkaji pendidikan Islam, marilah memanfaatkan warisan budaya bangsa sebagai sumber kajian keilmuan agar muncul karya-karya bernas yang berinovasi dengan sumber-sumber naskah keagamaan yang tidak terhitung jumlahnya. Semoga tulisan ini bermanfaat bagi pengembangan dan perkembangan ilmu pengetahuan pendidikan Islam. 


\section{G. Daftar Pustaka}

Al-Abrasyiy. Dasar-dasar Pokok Pendidikan Islam. Jakarta: Bulan Bintang, 2013

Al-Syaibaniy. Filsafat Pendidikan Islam. Terj. Hasan Langgulung. Jakarta: Bulan Bintang, 1979.

Ambary, Hasan Muarif. "Kontribusi Filologi, Sejarah dan Arkeologi bagi Pengembangan Kebudayaan Indonesia." Jurnal Lektur Keagamaan, Vol. 3, No. 1 (2005): 90-103

Chambert-Loir dan Faturrahman. Panduan Koleksi Naskah-naskah Nusantara. Jakarta: Yayasan Obor Indonesia, 1999.

Drajat, Zakiah. Ilmu Pendidikan Islam. Jakarta: Bumi Aksara, 2012

Ekadjati, Edi S. Naskah Sunda. Bandung: Lembaga Penelitian Unpad bekerjasama dengan The Toyota Foundation, 1988.

Endaswara, Suwardi. Metode, Teori, Teknik Penelitian Kebudayaan. Yogyakarta: Pustaka Widyataman, 2006

Fathurrahman, Oman, et.al. Filologi dan Islam Indonesia. Jakarta: Balitbang dan Diklat Keagamaan Depag RI, 2010.

Fathurrahman, Oman. Filologi Indonesia: Teori dan Metode. Jakarta: Prenadamedia, 2015

Faturrahman, Oman. "Filologi Plus: Metode dan Pendekatan." Paper pada Temu Peneliti Naskah Keagaman Puslitbang Lektur Keagamaan. Bukittinggi: 7-10 Juli 2010.

Faturrahman, Oman. "Filologi Plus: Metode dan Pendekatan." Paper pada Temu Peneliti Naskah Keagaman Puslitbang Lektur Keagamaan, Bukittinggi: 7-10 Juli 2010 .

Galberaith, John Kenmeth. Hakikat Kemiskinan Massa. Terj. Tom Anwar. Jakarta: PN Sinar Harapan, 1983

Hamidi, U.U. Islam dan Masyarakat Melayu di Riau. Pekanbaru: UIR Press,1999

Hamiri, Yusuf dan Basuni, Firdaus. Metodologi Pengajaran Agama Islam. Palembang: IAIN Raden Fatah Press, 2005

Hamka. Sejarah Umat Islam. Jilid II. Jakarta: Bulan Bintang, 2012.

Hartono. Metodologi Penelitian. Pekanbaru: Zanafa Publising, 2011

Hashim, Muhammad Yusoff. Pensejarahan Melayu: Kajian tentang Tradisi Sejarah Melayu Nusantara. Kuala Lumpur: Dewan Bahasa dan Pustaka.

Hawi, Akmal. Kapita Selekta Pendidikan Islam. Palembang: IAIN Raden Fatah Press, 2005

Hermansoemantri, Emuch. Identifikasi Naskah. Bandung : FASA UNPAD, 1986.

Hitami, Munzir. Mengonsep Kembali Pendidikan Islam. Pekanbaru: Infinite Press. 2004

Ikram, Achdiati. "Sastra Lama sebagai Penunjang Pengembangan Sastra Modern." Majalah Bahasa dan Sastra, No . 2 (1976), 2. 
Ellya Roza, Mudasir: Naskah Melayu Digital: Sebuah Inovasi Sumber Kajian Pendidikan Islam Berbasis ICT

Keesing., Antropologi Budaya: Suatu Perpektif Kontemporer. Terj. Samuel Gunawan Jakarta: Gramedia,1991.

Kridalaksana, Harimukti. Masa Lampau Bahasa Indonesia: Sebuah Bunga Rampai. Yogyakarta: Sinar Harapan, 1991.

Maloeng, Lexy J. Metode Penelitian Kualitatif. Bandung: Rosdakarya, 1997.

Marimba, Ahmad D. Pengantar Filsafat Pendidikan Islam. Bandung: Alma'arif, 1999.

Muhadjir, Noeng. Metodologi Penelitian Kualitatif. Yogyakarta: Rake Sarasian, 2000

Nazir, Mohd. Metode Penelitian. Jakarta: Bina Aksara, 2000

Piah, Harun Mat. "Tamadun Melayu sebagai Asas Kebudayaan Kebangsaan, Suatu Tinjauan dan Justifikasi." Dalam Ismail Hussein (Penyelenggara). Tamadun Melayu. Jilid II. Kuala Lumpur: Dewan Bahasa dan Pustaka, 1989.

Pradotokusumo. Kakawin Gajah Mada: Sebuah Karya Sastra Abad ke-20 Suntingan Naskah Serta Telaah Struktur Tokoh dan Hubungan Antar Teks. Bandung: Binacipta,1986.

Pudjiastuti, Titik (Ed.). Filologia Nusantara. Jakarta: Pustaka Jaya, 1997

Roza, Ellya. "Aksara Arab-Melayu di Indonesia (Suatu Refleksi Historis)." Jurnal Sosial Budaya, Vol. 2, No. 1, (2005).

Roza, Ellya. "Aksara Arab-Melayu di Nusantara dan Sumbangsihnya dalam Pengembangan Khazanah Intelektual.” Tsaqafah Jurnal Peradaban Islam, Vol. 13, No.1 (2017): 178.

Roza, Ellya. "Internalisasi Nilai Islam dan Tamadun Melayu terhadap Perilaku Sosial Orang Melayu Riau.” Jurnal Toleransi:Media Komunikasi Umat Beragama, Vol. 6, No.1 (2014): 16-35.

Roza, Ellya. "Sejarah Keberadaan Aksara Arab-Melayu di Nusantara dan Peranannya untuk Membaca Khazanah Intelektual Naskah-Naskah Melayu." Paper yang disampaikan pada acara Seminar Internasional yang ditaja oleh Himpunan Mahasiswa Jurusan Pendidikan Bahasa Arab UIN Suska Riau Jumat 17 April 2015 di Islamic Center UIN Suska Riau.

Roza, Ellya. Naskah Melayu. Pekanbaru: Yayasan Pusaka, 2010

Sudirman, Ivan. "Perkembangan Hardware Komputer." Diunduh di www.ilmukomputer.com

Sugiyono. Metode Penelitian Kuantitatif Kualitatif dan $R$ \& D. Bandung: Alfabeta, 2013

Tim Penyusun. Kamus Besar Bahasa Indonesia. Jakarta: Departemen Pendidikan dan Kebudayaan RI, 2008.

Wijk, D. Gerth Van. Tata Bahasa Melayu. Terj. T.W. Kamil. Jakarta: Djambatan, 1985.

Vredenbergt. Metode dan Teknik Penelitian. Jakarta: Gramedia, 2002.

Yahya, Ismail; Hasan, Moh. Abdul Kholiq; dan Farkhan. Penerjemahan Manuskrip Masãil at-Ta'lím ke dalam Aksara Pegon Pada Abad ke-17 M. Surakarta: IAIN Surakarta Press bekerjasama dengan Pusat Studi Manuskrip Islam (PUSMI) dan Direktorat PTKI Kementerian Agama RI, 2018. 